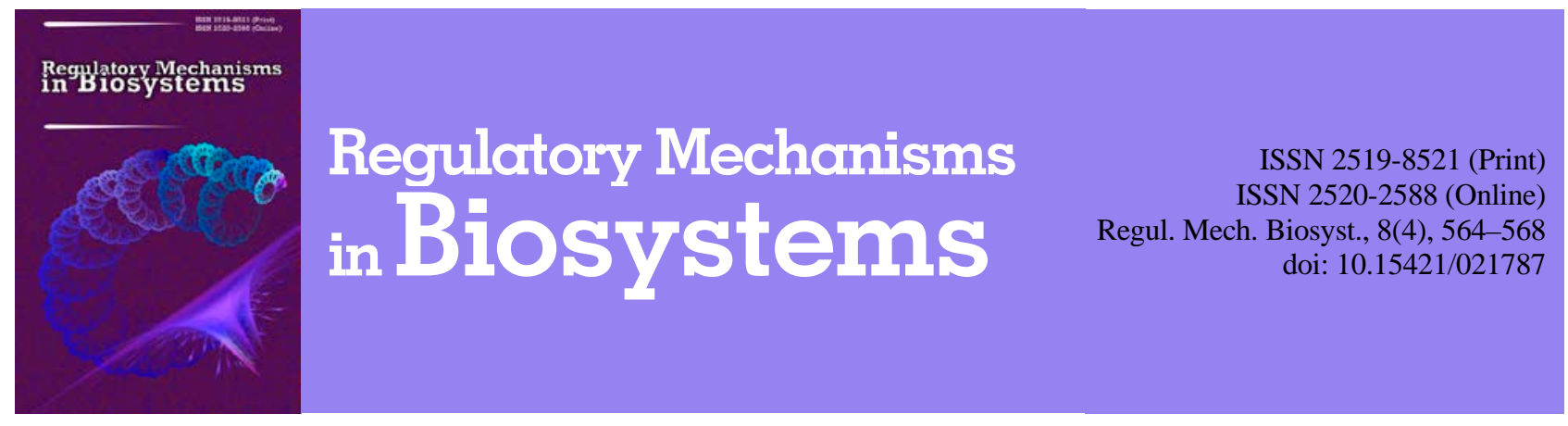

\title{
Biochemical markers of safety of nano-particles of metals on the model of isolated subcultural fractions of eukaryotes
}

\author{
M. Y. Roman’ko \\ National Scientific Center "Institute of Experimental and Clinical Veterinary Medicine", Kharkiv, Ukraine
}

Article info

Received 28.09.2017

Received in revised form 04.11.2017

Accepted 09.11.2017

Institute of Experimental and Clinical Veterinary Medicine, Pushkinska st., 83, Kharkiv, 61000, Ukraine.

Tel. +38-057-707-20-02

E-mail:

marina_biochem@ukr.net
Roman'ko, M. Y. (2017). Biochemical markers of safety of nano-particles of metals on the model of isolated subcultural fractions of eukaryotes. Regulatory Mechanisms in Biosystems, 8(4), 564-568. doi:10.15421/021787

Unique sizes and a high level of bioavailability allow nanoparticles of metals (NPMe) to come into direct contact with biological systems, with infectious agents, toxins, as well as with different chemical compounds and separate cell structures (proteins, lipids, nucleic acids). Other biological effects, including less toxicity than in microscopic substances, require attention to be paid to the study of the potential risk of using nanoparticles of each type in a particular way, therefore scientific support is absolutely necessary in this direction. It is believed that the cytotoxicity of nanomaterials is due to genomic and mutagenic effects, but the mechanical forces of interaction of NPMe with cells, obviously, will change not only cytological but also their metabolic reactions. Therefore, the purpose of this research was to determine the biochemical markers of safety (potential toxicity) of NPMe ( $\mathrm{Au}, \mathrm{Ag}, \mathrm{Cu}, \mathrm{Fe}, \mathrm{Co}, \mathrm{GFCo}, \mathrm{Zn}$, $\mathrm{MnO}_{2}$ ) on the model of isolated membrane and cytosolic fractions of eukaryotic test cells of CHO-K1 and U937 lines. Under conditions of preincubation of experimental samples of NPMe at a final concentration of $1 \mu \mathrm{g} / \mathrm{cm}^{3}$ by the metal with preparations of subcellular fractions of CHO-K1 and U937 (in the final amount of protein 150-200 $\mu \mathrm{g} / \mathrm{cm}^{3}$ ) for 3 minutes at $37 \pm 1{ }^{\circ} \mathrm{C}$, there was determined the magnitude of membrane ATP-ase and cytosolic LDH-ase activity compared to intact cells ("control"). According to the results of the research, colloidal dispersions of NPAg average size $\sim 30 \mathrm{~nm}, \mathrm{NPFe} \sim 100 \mathrm{~nm}, \mathrm{NPCu} \sim 70 \mathrm{~nm}$, and $\mathrm{NPMnO}_{2} \sim 50 \mathrm{~nm}$ are safe and biocompatible by their membranotropic effect on subcellular fractions of eukaryotic test cells, as evidenced by an increase in the level of membrane ATPase and cytosolic LDHase of test-cells CHO-K1, and the experimental samples NPCo, NPGFCo and NPZn average size of $\sim 100 \mathrm{~nm}$ are membrane-toxic, that is, dangerous. By the nature of the changes in the enzymatic activity of the test cells U937, the discrete dimensions of the membranotropic action of NPAu have been demonstrated: nanoparticles of size $\sim 10 \mathrm{~nm}$ caused the inhibition of the membrane $\mathrm{Na}^{+}, \mathrm{K}^{+}$-ATPase, and the size of $\sim 30 \mathrm{~nm}$ and $\sim 45 \mathrm{~nm}-$ its induction; nanoparticles of size $\sim 10, \sim 20$ and $\sim 30 \mathrm{~nm}$ induced cytosolic LDHase and the size of $\sim 45 \mathrm{~nm}$ - its inhibition relative to the control level of enzymes, so NPAu $\sim 10$ and $\sim 45 \mathrm{~nm}$ can be considered membrane toxic, and size $\sim 30 \mathrm{~nm}$ - safe and biocompatible for eukaryotic cells. Based on the hypothesis about the involvement of metabolism-dependent mechanisms of contact interaction of colloidal dispersions of experimental samples of NPMe with cells through membranotropic properties, the study of their potential danger or biocompatibility in further research can be carried out by determining the intensity of oxidation of the main structural components of biomembranes of cells - lipids and proteins and indicators of their AO-regulation.

Keywords: nanoparticles of metals; membrane ATPase; cytosolic LDHase; safety; biocompatibility; eukaryotic cell

\section{Біохімічні маркери безпечності наночастинок металів на моделі ізольованих субклітинних фракцій еукаріотів}

\author{
М. Є. Романько
}

Національний науковий цеентр «Інститут експериментальної і клінічної ветеринарної медицини» НААН, Харків, Україна

\footnotetext{
Унікальні розміри та значний рівень біодоступності дозволяють наночастинкам металів (NPMe) вступати в прямий контакт із біологічними системами, з інфекційними агентами, токсинами, а також із різними хімічними сполуками та окремими структурами клітин (протеїнами, ліпідами, нуклеїновими кислотами). Інші біологічні ефекти, у тому числі - менша токсичність, ніж у речовин у макророзмірному стані, вимагають приділяти увагу вивченню потенційного ризику використання наночастинок кожного виду окремим чином, тому науковий супровід цього напряму абсолютно необхідний. Мета досліджень - визначити біохімічні маркери безпечності (потенційної токсичності) $\mathrm{NPMe}\left(\mathrm{Au}, \mathrm{Ag}, \mathrm{Cu}, \mathrm{Fe}, \mathrm{GFCo}, \mathrm{Co}, \mathrm{Zn}, \mathrm{MnO}_{2}\right)$ на моделі ізольованих мембранної та цитозольної фракцій еукаріотичних тест-клітин ліній CHO-K1 та U937. За преінкубації дослідних зразків NPMе у кінцевій концентрації 1 мкг/см³ за металом із препаратами субклітинних фракцій СНO-K1 і U937 (у кінцевій кількості білка 150-200 мкг/см ${ }^{3}$ ) упродовж 3 хвилин за температури $37^{\circ} \mathrm{C}$ визначали мембранну АТР-азну та цитозольну ЛДГ-азну активність порівняно з показниками інтактних клітин (контроль). Колоїдні
} 
дисперсії NPAg середнього розміру 30 нм, NPFe 100 нм, NPCu 70 нм та NPMnO 50 нм безпечні та біосумісні за їх мембранотропної дії щодо субклітинних фракцій еукаріотичних тест-клітин, про що свідчить підвищення рівня мембранної АТР-ази та цитозольної ЛДГ-ази тест-клітин CHO-K1, а дослідні зразки NPCo, NPGFCo i NPZn розміром 100 нм - мембранотоксичні, тобто небезпечні. За характером змін ферментативної активності в ізольованих мембранах тест-клітин U937 доведено дискретні розміри мембранотропної дії NPAu: наночастинки металу розміром 10 нм викликали інгібування мембранної активності $\mathrm{Na}^{+} \mathrm{K}^{+}$-ATP-ази, а розміром 30 і 45 нм - іiі індукцію; наночастинки металу розміром 10, 20 і 30 нм індукували активність цитозольної ЛДГ-ази, а розміром 45 нм - ії пригнічення відносно контрольного рівня ензимів, тому NPAu розміром 10 і 45 нм можна вважати мембранотоксичними, а розміром 30 нм - безпечними та біосумісними для еукаріотичних клітин.

Ключові слова: наночастинки металів; мембранна АТР-аза; цитозольна ЛДГ-аза; безпечність; біосумісність; еукаріотична клітина

\section{Вступ}

Унікальні розміри та значний рівень біодоступності дозволяють наночастинкам, зокрема наночастинкам металів (NPMe), вступати у прямий контакт із біологічними системами, з інфекційними агентами, токсинами, а також із різними хімічними сполуками та окремими структурами клітин (протеїнами, ліпідами, нуклеїновими кислотами) (Elder et al., 2002; Silva, 2004; Oberdörster et al., 2005; Yan et al., 2007; Dutta et al., 2007; Owino et al., 2008; Xu et al., 2008; Cardinal et al., 2008). Інші біологічні ефекти, у тому числі менша токсичність (Kagan et al., 2005; Kabanov 2006; Lewinski et al., 2008; Jahnen-Dechent and Simon, 2008), ніж у речовин у макророзмірному стані, вимагають приділяти увагу вивченню потенційного ризику використання наночастинок кожного виду окремим чином, тому науковий супровід у цьому напрямку абсолютно необхідний.

Відомі наукові праці присвячені уявленню цитотоксичної дії наночастинок взагалі на рівні культур клітин або стосовно інших видів - карбонових нанотрубок, фулеренів, модифікованих наноалмазів (Weyermann et al., 2005; Chen et al., 2006, 2008; Powers et al., 2006). Цитотоксичність наноматеріалів зумовлена гено- та мутагенними ефектами (Jia et al., 2005; Brunner et al., 2006; Lynch et al., 2007), але механічні сили взаємодії NPMe 3 клітинами, очевидно, будуть змінювати не лише цитологічні, а й метаболічні реакції.

Існують розбіжності між поглядами вчених щодо небезпечності наночастинок ауруму (NPAu): одні визначають їх нетоксичними через інертність металу в діапазоні 0,5-100 нм, а інші - цитотоксичними (Goodman et al., 2004; Connor et al., 2005; Shukla et al., 2005). Токсичні ефекти наночастинок аргентуму (NPAg), навпаки, вважають очевидними через відому ïx біоцидну дію відносно клітин мікроорганізмів (Egorova et al., 2001; Alt et al., 2004; Borysevych and Borysevych, 2010); бракує досліджень in vitro. Токсичність наночастинок купруму (NPCu) i феруму (NPFe) в основному досліджена в системі in vivo за різними шляхами введення та проявляє чітку розмірну залежність (Gupta and Gupta, 2005; Zhu et al., 2008; Sljunjaeva, 2012). Публікації щодо біологічних ефектів наночастинок інших металів обмежені за кількістю, не вистачає грунтовного розуміння біохімічних механізмів їх природи.

Отже, визначення особливостей модуляції NPMe біохімічних процесів у клітині в цілому та їі окремих структурах відкриває нові перспективи у фундаментальному розумінні їх впливу на стан і функціональну активність мікроорганізмів. Саме тому мета наших досліджень - визначити біохімічні маркери безпечності (потенційної токсичності) наночастинок металів (Аu, $\mathrm{Ag}, \mathrm{Cu}, \mathrm{Fe}, \mathrm{GFCo}, \mathrm{Co}, \mathrm{Zn}, \mathrm{MnO}_{2}$ ) на моделі ізольованих мембранної та цитозольної фракцій еукаріотичних тест-клітин ліній СНО-К1 та U937.

\section{Матеріал і методи досліджень}

Як біологічні моделі використовували лінії пухлинних клітин гістіоцитарної лімфоми людини U937 та лінії клітин яєчника китайського хом'ячка СНО-К1.

Тест-клітини лінії U937 культивували у стандартному середовищі RPMI 1640, що містить 10\% ембріональної сироватки BPX, а CHO-К1 - у середовищі F10, що містить 5\% ембріональної сироватки ВРХ, за температури $37,0 \pm 1,0{ }^{\circ} \mathrm{C}$ у $\mathrm{CO}_{2}$ інкубаторі в атмосфері $5 \% \mathrm{CO}_{2}$ до титру $5 \cdot 10^{6}$ кл./. $\mathrm{cm}^{3}$.
Життєздатність клітин оцінювали за допомогою фарбування $з$ використанням $0,3 \%$ розчину трипанового синього. Кількість живих клітин складала не менше 90\%.

Виділення цитозольної та мембранної фракцій еукаріотичних тест-клітин проводили, як описано Maianski et al. (2004): клітини відмивали від живильного середовища ФСБ, ресуспендували у буфері для екстракції цитозолю (250 мМ сахароза, $70 \mathrm{MM} \mathrm{KCl,} 250$ мкг/мл дигітонін, 1 мМ ФМСФ, 5 мМ ЕДТА на ФСБ-буфері, $\mathrm{pH} 7,4)$ упродовж 20 хвилин за температури $40{ }^{\circ} \mathrm{C}$ за постійного перемішування, центрифугували за 1000 об./хв, надосад збирали як цитозольну фракцію клітин; осад ресуспендували у середовищі (50 мМ Трис-HCl, 10 мМ $\mathrm{NaCl}, 10$ мМ $\mathrm{MgCl}_{2}, 2$ мМ ЕДТА, 1\% тритон Х100, 10\% гліцерин, $\mathrm{pH} 7,5)$ упродовж 10 хвилин, постійно перемішуючи, центрифугували за $10000 \mathrm{~g}$ та отримували осад - сумарну мембранну фракцію (СМФ) клітин.

Препарати субклітинних фракцій характеризували за вмістом білка методом (Lowry et al., 1951) та зберігали за температури $-20 \pm 1{ }^{\circ} \mathrm{C}$; повторного заморожування не допускали. Як стандартний білок для побудови калібрувальної кривої використовували бичачий сироватковий альбумін (BSA).

У дослідженні використані такі колоїдні розчини NPMe: наночастинки ауруму (NPAu) середнього розміру 10, 20, 30 та 45 нм із вихідною концентрацією за металом 38,6 мкг $/ \mathrm{cm}^{3}$ та у діапазоні

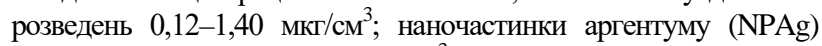
30 нм із концентрацією 86,4 мкт/ $\mathrm{cm}^{3}$; наночастинки феруму (NPFe) 100 нм із концентрацією 3174,0 мкг/ $\mathrm{cm}^{3}$; наночастинки гексаціано-

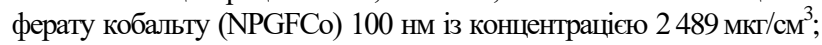
наночастинки кобальту (NPCo) $100 \mathrm{HM}$ iз концернтрацією

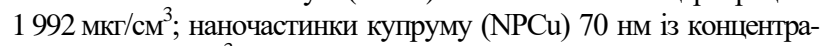
цією 2679 мкг $/ \mathrm{cm}^{3}$; наночастинки цинку (NPZn) 100 нм із концернтрацією 2407 мкг $/ \mathrm{cm}^{3}$; наночастинки двоокису мангану $\left(\mathrm{NPMnO}_{2}\right)$ 50 нм із концентрацією 2785 мкг $/ \mathrm{cm}^{3}$.

Колоїдні розчини NPMе отримували методом хімічної конденсації шляхом відновлення відповідних солей металів у водному середовищі (Percov, 1976), який дозволяє отримувати стійкі водні дисперсії наночастинок певного розміру. Середній розмір $\mathrm{NPMe} \mathrm{обчислювали} \mathrm{методом} \mathrm{лазерно-кореляційної} \mathrm{спектрометрії}$ (Zetasizer-3; Malvern Instruments Ltd, Великобританія), що дозволяє $з$ високою точністю визначити константи швидкості дифузії частинок і обчислити їх гідродинамічний діаметр, виходячи 3 припущення щодо їх сферичної геометрії (Rawle, 1994).

За преінкубації дослідних зразків NPMе у кінцевій концен-

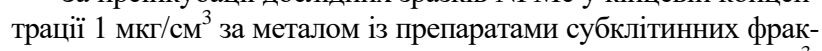

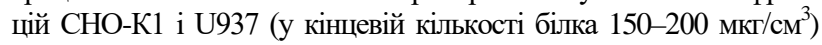
упродовж 3 хвилин за температури $37 \pm 1{ }^{\circ} \mathrm{C}$ визначали мембранну АТР-азну та цитозольну ЛДГ-азну активність порівняно $з$ показниками інтактних клітин (контроль). У контрольну пробу замість NPMе додавали Трис-HCl буфер або ФСБ.

Активність питомої АТРази (КФ 3.6.3.6) у СМФ тест-клітин визначали спектрофотометрично, як описано Prohorova (1982), за швидкістю накопичення неорганічного фосфору в результаті гідролізу АТР у середовищі інкубації (10 мМ трис-HCl, $3 \mathrm{MM} \mathrm{MgCl}_{2}$, 3 мМ АТР, рН 7,5) упродовж 10 хвилин; виражали у відносних одиницях $\mathrm{A} / \mathrm{A}_{0}$. Реакцію ініціювали уведенням до середовища ін.кубації 0,1 см ${ }^{3}$ дослідної проби (кількість мембранного білка - 1520 мкг $\left./ \mathrm{cm}^{3}\right)$. Контролем на неферментативний гідроліз АТР слугувало середовище інкубації за відсутності в ньому СМФ; контролем на ендогенний $\mathrm{P}_{\mathrm{i}}$ - середовище, що містило лише СМФ у водному розчині. 
Активність ЛДГази (КФ 1.1.1.27) у цитозольній фракції тестклітин визначали спектрофотометрично за швидкістю окиснення NADH за довжини хвилі 340 нм, як описано Prohorova (1982), у середовищі інкубації (50 мМ К-фосфатний буфер, 0,3 мМ Na-пірувату, 9 мM NADH, pH 7,5); виражали у відносних одиницях $\mathrm{A} / \mathrm{A}_{0}$.

Реакцію ініціювали внесенням до середовища інкубації $0,1 \mathrm{~cm}^{3}$ дослідної проби цитозольної фракції. Реєстрацію показника проводили кожні 30 секунд упродовж 3-5 хвилин, розраховуючи середне значення зміни оптичної густини проби упродовж 1 хвилини. Токсичними вважали зразки NPMе у випадку інгібування активності АТРази дослідної проби за взаємодії з такими не менше ніж на 20\%, та у випадку стимуляції активності ЛДГази дослідної проби за взаємодії з такими не менше ніж на $50 \%$, порівняно з рівнем ферментативної активності у контрольній пробі. Вірогідність отриманих результатів оцінювали за критерієм Стьюдента після перевірки нормальності розподілу показників. Для одержання статистично вірогідних результатів під час виконання досліджень на культурах клітин і субклітинних фракціях, визначення параметрів проводили у 5-кратній повторності з трьома пробами.

\section{Результати}

Результати (рис. 1), свідчать, що за впливу дослідних зразків $\mathrm{NPAg}, \mathrm{NPFe}, \mathrm{NPCu}$ та $\mathrm{NPMnO}_{2}$ не реєстрували вірогідного галь- мування активності мембранної АТР-ази відносно ії значень у фракціях інтактних тест-клітин СНО-К1 (контроль). Але за контактної взаємодії ізольованих СМФ тест-клітин із NPCo і NPGFCo, навпаки, визначали вірогідне зниження активності АТРази у середньому на $22,3 \%$ та $26,1 \%$, а за впливу NPZn - лише тенденцію до зниження активності цього ензиму, що складало $10,8 \%$ відносно іiі значень у контролі (СМФ інтактних клітин). Внаслідок преінкубації ізольованих цитозольних фракцій тест-клітин СНОK1 із дослідними зразками всіх видів NPMе не реєстрували вірогідних змін активності ЛДГази відносно ії значень в інтактних клітин (контроль) (рис. 1). Виняток складало збільшення рівня ЛДГазної активності за взаємодії з NPGFCо та NPCu в середньому на $19,4 \%$ та $38,9 \%(\mathrm{P}<0,05)$, відповідно.

Під час визначення впливу NPAu у діапазоні розмірних значень на активність мембранної $\mathrm{Na}^{+}, \mathrm{K}^{+}$-АТРази тест-клітин U937 встановлено (рис. 2), що NPMе в усьому концентраційному діапазоні середнього розміру (10 нм) інгібували ферментативну активність у середньому на 70\%, а розміром 30 і 45 нм індукували іï у межах 20-40\% ( $<0,05)$, відповідно, відносно рівня активності цього ензиму у СМФ інтактних клітин (контроль). Виняток складало зниження $(\mathrm{P}<0,05)$ активності цього ензиму у СМФ клітин за впливу NPAu середнього розміру $(20 \mathrm{HM})$ у концентрації 0,30 мкг $/ \mathrm{cm}^{3}$ за металом.

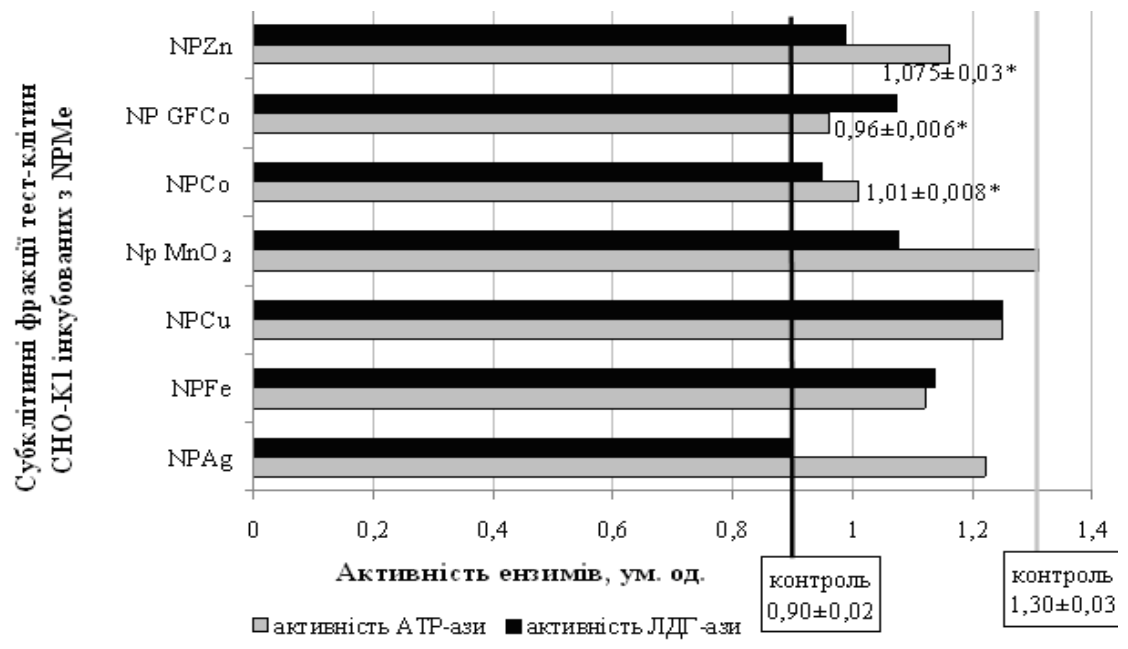

Рис. 1. Активність мембранної АТРази та цитозольної ЛДГази тест-клітин СНО-К1 за контактної взаємодії з NРМе (ум. од.): $\mathrm{M} \pm \mathrm{m} ; \mathrm{n}=5 ; \mathrm{P}<0,05$ відносно контролю (СМФ інтактних клітин)

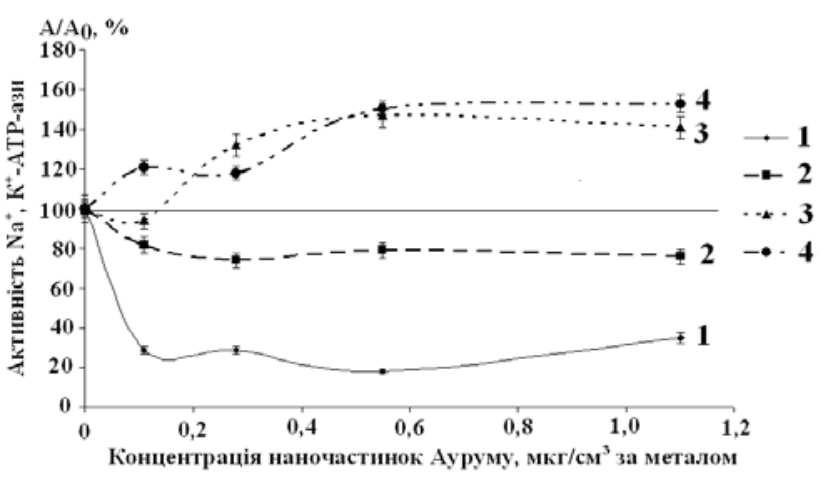

Рис. 2. Активність мембранної $\mathrm{Na}^{+}, \mathrm{K}^{+}$-АТРази $\left(\mathrm{A} / \mathrm{A}_{0}, \%\right)$ тест-клітин U937 за контактної взаємодії з NPAu середнього розміру: $1-10 \mathrm{Hм}, 2-20 \mathrm{Hм}, 3-30 \mathrm{Hм}, 4-45 \mathrm{Hм}(\mathrm{n}=5$,

$\mathrm{P}<0,05$ - відносно контролю (СМФ інтактних клітин) - $\left.\mathrm{A}_{0}\right)$ :

за 100\% прийнято величину АТРазної активності СМФ інтактних клітин лінії U937 (контроль) за відсутності впливу NPAu

Дослідження впливу дослідних NPAu на активність ЛДГази цитозольної фракції тест-клітин U937 показало (рис. 3), що
NPMe викликають підвищення іiі активності у діапазоні кон-

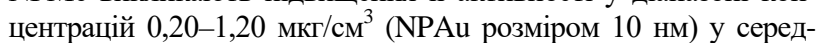
ньому складало $4,0-4,5$ раза, у концентраціях $0,18-0,70$ мкг $/ \mathrm{cm}^{3}$ за металом (NPAu розміром 20 і 30 нм) - 1,5-2,0 раза $(\mathrm{P}<0,05)$ відповідно відносно ії контрольного рівня.

За впливу NPAu середнього розміру 45 нм у концентрацій-

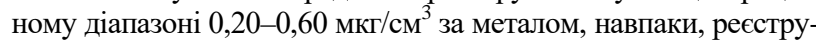
вали інгібування активності цитозольної ЛДГази, зниження значень склало в середньому 5,0 раза $(\mathrm{P}<0,05)$ відносно іï базового рівня (контроль).

\section{Обговорення}

Еукаріотичні клітини мають вищу організацію порівняно 3 прокаріотичними, що знаходить відображення в їх метаболічних процесах (Artjuhov and Nakvasina, 2000). АТРаза - один із ключових ферментів енергетичного метаболізму клітини, завдяки якому відбувається формування різниці електрохімічних потенціалів на мембрані (Basnak'jan et al., 1981; Ulberg, 2005; Danylovych et al., 2007). Фермент локалізується у плазматичній мембрані клітини таким чином, що його субодиниці експоновані як до цитоплазми, так і до зовнішнього середовища, тому активність може бути використана як індикатор стресового впливу будь-якого фактора ризику. 
Поряд із десятьма цитозольними ферментами, які перетворюють глюкозу на піруват, ЛДГазі у тому числі властиво забезпечувати синтез АТР за відсутності оксигену, в анаеробних умовах (Artjuhov and Nakvasina, 2000). При цьому акцептором гідрогену слугує піровиноградна кислота, яка перетворюється на лактат, що виконує функцію резервуара відновлених еквівалентів.

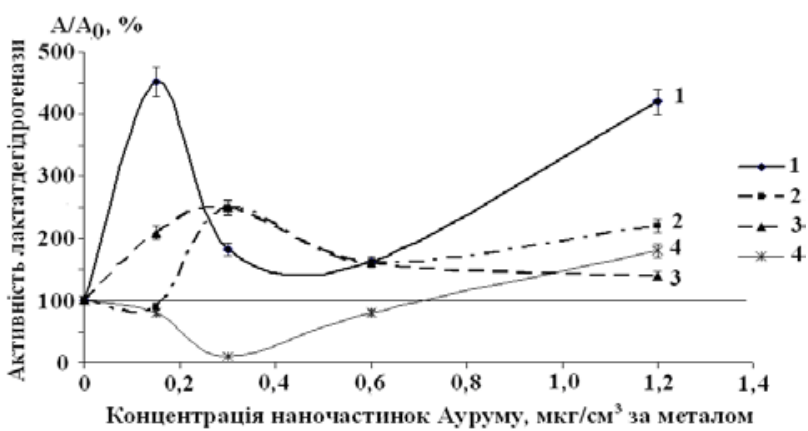

Рис. 3. Активність цитозольної ЛДГази $\left(\mathrm{A} / \mathrm{A}_{0}, \%\right)$ тест-клітин U937 за контактної взаємодії з NPAu середнього розміру: $1-10$ нм, $2-20$ нм, $3-30$ нм, $4-45$ нм (n $=5, \mathrm{P}<0,05-$ відносно контролю (цитозольна фракція інтактних клітин) -

$\mathrm{A}_{0}$ ): за 100\% прийнято ЛДГазну активність цитозольної фракції інтактних клітин лінії U937 (контроль) за відсутності впливу NPAu

Виходячи $з$ того, що цитоплазматична мембрана клітин ушкоджується у першу чергу, оскільки вона слугує бар'єром між поза- та внутрішньоклітинним оточенням і забезпечує селективний транспорт речовин (Rapoport et al., 1982; Ivanytsia and Rakhimova, 2002; Kharchuk, 2005), установлені нами зміни активності АТРази та ЛДГази у субклітинних фракціях еукаріотичних тестклітин за контактної взаємодії з дослідними зразками NPMе дозволяють використовувати ферментативну активність як системний біохімічний маркер під час тестування безпечності та біосумісності in vitro. Отримані результати щодо мембранотоксичної дії колоїдних дисперсій NPCo, NPGFCo i NPZn розміром 100 нм та NPAu розміром 10 і 45 нм вимагають відповідального підходу під час їх використання у сучасних біотехнологіях, а з іншого боку подальшого вивчення механізмів потенційної небезпечності та біосумісності NPMe із залученням інших маркерів тестування як у системі in vitro, так і in vivo. Колоїдні дисперсії NPAg 30 нм, NPFe 100 нм, NPCu 70 нм та NPMnO 250 нм, навпаки, слід вважати безпечними та біосумісними за мембранотропною дією щодо субклітинних фракцій еукаріотичних тест-клітин, про що вказує підвищення рівня мембранної АТРази та цитозольної ЛДГази $(\mathrm{P}<0,05)$ CHO-К1.

Низка авторів (Yamakoshi et al., 2003; Li et al., 2003; Shvedova et al., 2004; Garcon et al., 2006) вважає, що механізми цитотоксичних ефектів наноматеріалів різного походження (карбонових нанотрубок, NPMe, фулеренів, нанопорошків тощо) пов'язані з формуванням окиснювального стресу та накопиченням токсичних продуктів ліпопероксидації, тому вважаємо за доцільне у подальших експериментах зосередитися на визначенні впливу дослідних зразків NPMe на структурно-функціональний стан основних компонентів біомембран клітин - ліпідів і протеїнів.

\section{Висновки}

За результатами досліджень установлено, що колоїдні дисперciï NPAg 30 нм, NPFe 100 нм, NPCu 70 нм та NPMnO 250 нм безпечні та біосумісні за мембранотропною дією щодо субклітинних фракцій еукаріотичних тест-клітин, про що свідчить підвищення рівня мембранної АТРази та цитозольної ЛДГази $(\mathrm{P}<0,05)$ CHO-K1, а дослідні зразки NPCo, NPGFCo i NPZn розміром 100 нм - мембранотоксичні, тобто небезпечні.

За характером змін ферментативної активності у субклітинних фракціях U937 доведені дискретні розміри мембранотропної діï NPAu: наночастинки розміром 10 нм викликали інгібування мембранної $\mathrm{Na}^{+}, \mathrm{K}^{+}$-АТРази, а розміром 30 і 45 нм - іiі індукцію; наночастинки розміром 10, 20 і 30 нм справляли індукцію цитозольної ЛДГази, а розміром 45 нм - іiі пригнічення відносно контрольного рівня. Тому NPAu розміром 10 i 45 нм можна вважати мембранотоксичними, а 30 нм - безпечними та біосумісними для еукаріотичних клітин.

Спираючись на висунуту гіпотезу щодо участі метаболізм-залежних механізмів контактної взаємодії колоїдних зразків NPMе 3 клітинами через мембранотропні властивості, стан їх потенційної небезпечності або біосумісності у подальших дослідженнях може бути з'ясований через визначення інтенсивності окиснення основних компонентів біомембран клітин - ліпідів та білків, а також показників їх АO-регуляції.

Автор висловлює подяку канд. біол. наук Т. Г. Грузіній і канд. біол. наук Л. С. Рєзніченко (Інститут біоколоїдної хімії імені Ф. Д. Овчаренка НАН України) за допомогу в синтезі наночастинок металів.

\section{References}

Alt, V., Bechert, T., Steinrücke, P., Wagener, M., Seidel, P., Dingeldein, E., Dormann, E., \& Schnettler, R. (2004). An in vitro assessment of the antibacterial properties and cytotoxicity of nanoparticulate silver bone cement. Biomaterials, 25(18), 4383-4391.

Artjuhov, V. G., \& Nakvasina, M. A. (2000). Biologicheskie membrany: Strukturnaja organizacija, funkcii, modifikacija fiziko-himicheskimi agentami [Biological membranes: Structural organization, functions, modification to physicochemical agents]. Izdatel'stvo Voronezhskogo Universiteta, Voronezh (in Russian).

Basnak’jan, I. A., Borovkova, V. M., \& Kuz’min, S. I. (1981). Patologija i fiziologija mikrobov [Pathology and physiology of microbes]. Zhurnal Mikrobiologii, Jepidemiologii i Immunobiologii, 9, 14-19 (in Russian).

Borysevych, V. B., \& Borysevych, B. V. (2010). Antibacterial properties and chemotherapeutic activity of nanoacquachelates of metals [Antybakterialni vlastyvosti ta khimioterapevtychna aktyvnist nanoakvakhelativ metaliv]. In: Borysevych, V. B., \& Kaplunenko, V. H. (Eds.). Nanomaterials in biology. Basic nanoveterinary [Nanomaterialy v biolohii. Osnovy nanoveterynarii]. Avitsena, Kyiv. pp. 27-33 (in Ukrainian).

Brunner, T. J., Wick, P., Manser, P., Spohn, P., Grass, R. N., Limbach, L. K., Bruinink, A., \& Stark, W. J. (2006). In vitro cytotoxicity of oxide nanoparticles: Comparison to asbestos, silica, and the effect of particle solubility. Environmental Science and Technology, 40(14), 4374-4381.

Cardinal, J., Klune, J. R., Chory, E., Jeyabalan, G., Kanzius, J. S., Nalesnik, M., \& Geller, D. A. (2008). Non-invasive radiofrequency ablation of cancer targeted by gold nanoparticles. Surgery, 144(2), 125-132

Chen, P. C., Mwakwari, S. C., \& Oyelere, A. K. (2008). Gold nanoparticles: From nanomedicine to nanosensing. Nanotechnology, Science and Applications, 1 , 45-65.

Chen, Z., Meng, H., Xing, G., Chen, C., Zhao, Y., Jia, G., Wang, T., Yuan, H., Ye, C., Zhao, F., Chai, Z., Zhu, C., Fang, X., Ma, B., \& Wan, L. (2006). Acute toxicological effects of copper nanoparticles in vivo. Toxicology Letters, 163(2), 109-120.

Connor, E. E., Mwamuka, J., Gole, A., Murphy, C. J., \& Wyatt, M. D. (2005). Gold nanoparticles are taken up by human cells but do not cause acute cytotoxicity. Small, 1(3), 325-327.

Danylovych, G. V., Gruzina, T. G., Ulberg, Z. R., \& Kosterin, S. O. (2007). Vplyv ionnoho ta koloidnoho zolota na ATR-hidrolazni fermentni systemy v membrani mikroorhanizmiv Bacillus sp. B4253 ta Bacillus sp. V4851 [Effect of ionic and colloid gold on ATP-hydrolase fermentative systems in membrane of Bacillus sp. B4253 and Bacillus sp. B4851]. Ukrainskyi Biokhimichnyi Zhurnal, 79(4), 46-51 (in Ukrainian).

Dutta, D., Sundaram, S. K., Teeguarden, J. G., Riley, B. J., Fifield, L. S., Jacobs, J. M., Addleman, S. R., Kaysen, G. A., Moudgil, B. M., \& Weber, T. J. (2007). Adsorbed proteins influence the biological activity and molecular targeting of nanomaterials. Toxicological Sciences, 100, 303-315.

Egorova, E. M., Revina, A. A., Rostovshhikova, T. N., \& Kiseleva, O. I. (2001). Baktericidnye i katalicheskie svojstva stabil'nyh metallicheskih nanochastic $\mathrm{v}$ obratnyh micellah [Bactericidal and catalytic properties of stable metallic nanoparticles in inverse micelles]. Vestnik Moskovskogo universiteta. Serija 2: Himija, 42(5), 332-338 (in Russian).

Elder, A. C. P., Gelein, R., Azadniv, M., Frampton, M., Finkelstein, J., \& Oberdörster, G. (2002). Systemic interactions between inhaled ultrafine particles and endotoxin. The Annals of Occupational Hygiene, 46(s1), 231-234. 
Garçon, G., Dagher, Z., Zerimech, F., Ledoux, F., Courcot, D., Aboukais, A., Puskaric, E., \& Shirali, P. (2006). Dunkerque City air pollution particulate matter-induced cytotoxicity, oxidative stress and inflammation in human epithelial lung cells (L132) in culture. Toxicology in Vitro, 20(4), 519-528.

Goodman, C. M., McCusker, C. D., Yilmaz, T., \& Rotello, V. M. (2004). Toxicity of gold nanoparticles functionalized with cationic and anionic side chains. Bioconjugate Chemistry, 15(4), 897-900.

Gupta, A. K., \& Gupta, M. (2005). Synthesis and surface engineering of iron oxide nanoparticles for biomedical applications. Biomaterials, 26(18), 3995-4021.

Ivanytsia, V. I., \& Rakhimova, E. L. (2002). Zhiznesposobnost' liofilizirovannyh kletok Myxococcus xanthus UCM 10041 i Polyangium cellulosum UCM $10043 \mathrm{v}$ prisutstvii razlichnyh antioksidantov [The viability of lyophilized Myxococcus xanthus cells UCM 10041 and Polyangium cellulosum UCM 10043 in the presence of various antioxidants]. Mikrobiologichny Zhurnal, 64(5), 3-9 (in Russian).

Jahnen-Dechent, W., \& Simon, U. (2008). Function follows form: Shape complementarity and nanoparticle toxicity. Nanomedicine, 3(5), 601-603.

Jia, G., Wang, H., Yan, L., Wang, X., Pei, R., Yan, T., Zhao, Y., \& Guo, X. (2005). Cytotoxicity of carbon nanomaterials: Single-wall nanotube, multiwall nanotube, and fullerene. Environmental Science and Technology, 39(5), $1378-1383$.

Kabanov, A. V. (2006). Polymer genomics: An insight into pharmacology and toxicology of nanomedicines. Advanced Drug Delivery Reviews, 58(15), 1597-1621.

Kagan, V. E., Bayir, H., \& Shvedova, A. A. (2005). Nanomedicine and nanotoxicology: Two sides of the same coin. Nanomedicine: Nanotechnology, Biology and Medicine, 1(4), 313-316.

Kharchuk, I. A. (2005). Anabioz: Osnovne ponjatija i soprovozhdajushhie ego processy (obzor) [Anabiosis: Laws and accompanying its processes (Review)]. Jekologija Morja, 70, 62-78 (in Russian).

Lewinski, N., Colvin, V., \& Drezek, R. (2008). Cytotoxicity of nanoparticles. Small, 4(1), 26-49.

Li, N., Sioutas, C., Cho, A., Schmitz, D., Misra, C., Sempf, J., Wang, M., Oberley, T., Froines, J., \& Nel, A. (2002). Ultrafine particulate pollutants induce oxidative stress and mitochondrial damage. Environmental Health Perspectives, 111(4), 455-460.

Lowry, O. H., Rosenbrough, N. J., Farr, A. L., \& Randall, R. J. (1951). Protein measurement with the Folin phenol reagent. Journal of Biological Chemistry, 193(1), 265-275.

Lynch, I., Cedervall, T., Lundqvist, M., Cabaleiro-Lago, C., Linse, S., \& Dawson, K. A. (2007). The nanoparticle-protein complex as a biological entity; A complex fluids and surface science challenge for the 21st century. Advances in Colloid and Interface Science, 134-135, 167-174.

Maianski, N. A., Blink, E., Roos, D., \& Kuijpers, T. (2004). Rol' Omi/HtrA2 v kaspazonezavisimoj kletochnoj gibeli nejtrofilov cheloveka [Role of Omi/HtrA2 in a caspase-independent cell death of human neutrophils]. Citokiny i Vospalenie, 3(2), 47-51 (in Russian).

Oberdörster, G., Oberdörster, E., \& Oberdörster, J. (2005). Nanotoxicology: An emerging discipline evolving from studies of ultrafine particles. Environmental Health Perspectives, 113(7), 823-839.

Owino, J. H., Arotiba, O. A., Hendricks, N., Songa, E. A., Jahed, N., Waryo, T. T., Ngece, R. F., Baker, P. G. L., \& Iwuoha, E. I. (2008). Electrochemical immunosensor based on polythionine/gold nanoparticles for the determination of aflatoxin B1. Sensors (Basel), 8(12), 8262-8274.
Percov, A. V. (Ed.). (1976). Metodicheskie razrabotki k praktikumu po kolloidnoj himii [Methodical developments for the workshop on colloid chemistry]. Izdatel'stvo Moskovskogo Universiteta, Moscow (in Russian).

Powers, K. W., Brown, S. C., Krishna, V. B., Wasdo, S. C., Moudgil, B. M., \& Roberts, S. M. (2006). Research strategies for safety evaluation of nanomaterials. Part VI. Characterization of nanoscale particles for toxicological evaluation. Toxicological Sciences, 90(2), 296-303.

Prohorova, M. I. (Ed.). (1982). Metody biohimicheskih issledovanij (lipidnyj i jenergeticheskij obmen) [Methods of biochemical research (lipid and energy metabolism)] Izdatel'stvo Leningradskogo Universiteta, Leningrad (in Russian).

Rapoport, A. I., Markovskij, A. B., \& Beker, M. E. (1982). O povyshenii pronicaemosti vnutrikletochnyh membran pri obezvozhivanii-regidratacii drozhzhej Sacharomyces cerevisiae [On increasing the permeability of intracellular membranes during dehydration-yeast rehydration Sacharomyces cerevisiae]. Mikrobiologija, 51(6), 901-904 (in Russian).

Shukla, R., Bansal, V., Chaudhary, M., Basu, A., Bhonde, R. R., \& Sastry, M. (2005). Biocompatibility of gold nanoparticles and their endocytotic fate inside the cellular compartment: A microscopic overview. Langmuir, 21(23), 10644-10654.

Shvedova, A. A., Kisin, E., \& Murray, A. R. (2004). Exposure of human bronchial cells to carbon nanotubes caused oxidative stress cytotoxicity. Proceedings of the Society for Free Radical Research Meeting. European Section (Ioannina, Greece, 26-29 June 2003), 91-103.

Shvedova, A. A., Kisin, E., Keshava, N., Murray, A. R., Gorelik, O., Arepalli, S. Gandelsman, V. Z., \& Castranova, V. (2004). Cytotoxic and genotoxic effects of single wall carbon nanotube exposure on human keratinocytes and bronchial epithelial cells. The 227th American Chemistry Society National Meeting (Anaheim, CA, 28 March-1 April 2004): Abstracts.

Silva, G. A. (2004). Introduction to nanotechnology and its applications to medicine. Surgical Neurology, 61(3), 216-220.

Sljunjaeva, M. K. (2012). Izmenenie aktivnosti indikatornyh fermentov syvorotki krovi pri podkozhnom vvedenii nanochastic zheleza [Change in the activity of indicator serum enzymes with subcutaneous injection of iron nanoparticles]. Bjulleten’ Medicinskih Intemet-Konferencij, 2(4), 181 (in Russian).

Ulberg, Z. R. (2005). Kolloidno-himicheskie svojstva biologicheskih nanosistem. Biomembrany [Colloid-chemical properties of biological nanosystems. Biomembranes]. In: Ulberg, Z. R. (Ed.). Kolloidno-himicheskie osnovy nanonauki [Colloid-chemical fundamentals of nanoscience] Akademperiodika, Kiev. pp. 199-237 (in Russian).

Weyermann, J., Lochmann, D., \& Zimmer, A. (2005). A practical note on the use of cytotoxicity assays. International Journal of Pharmaceutics, 288(2), 369-376.

Xu, C., Tung, G. A., \& Sun, S. (2008). Size and concentration effect of gold nanoparticles on X-ray attenuation as measured on computed tomography. Chemistry of Materials, 20(13), 4167-4169.

Yamakoshi, Y., Umezawa, N., Ryu, A., Arakane, K., Miyata, N., Goda, Y., Masumizu, T., \& Nagano, T. (2003). Active oxygen species generated from photoexcited fullerene $\left(\mathrm{C}_{60}\right)$ as potential medicines: $\mathrm{O}_{2} \cdot$ versus ${ }^{1} \mathrm{O}_{2}$. Journal of the American Chemical Society, 125(42), 12803-12809.

Yan, F., Chen, J., \& Ju, H. (2007). Immobilization and electrochemical behavio of gold nanoparticles modified leukemia K562 cells and application in drug sensitivity test. Electrochemistry Communications, 9(2), 293-298.

Zhu, M.-T., Feng, W.-Y., Wang, B., Wang, T.-C., Gu, Y.-Q., Wang, M., Wang, Y., Ouyang, H., Zhao, Y. L., \& Chai, Z.-F. (2008). Comparative study of pulmonary responses to nano- and submicron-sized ferric oxide in rats. Toxicology, 247(2-3), 102-111. 